\title{
Antipathy to art in a recalcitrant court
}

\author{
by Paul Kearns
}

The author examines the seminal case law produced by the European Court of Human Rights on freedom of artistic expression and its ethical boundaries, and analyses why the Court has been so reluctant to support artistic freedom: instead, it consistently reinforces local national measures aimed at preserving the ambiguous concept of "public morality". The article focuses on the cardinal constitutional laws of obscene and blasphemous libel, laws which are designed to fulfil the paternalistic function of insulating the moral approaches of citizens from what is considered by legislators and judges to be undesirable corruption.

\section{INTRODUCTION}

A rtistic freedom is only implicitly regulated under Article 10 of the European Convention on Human Rights, a provision which is phrased in comparatively general terms. Article 10 provides:

"1. Everyone has the right to freedom of expression. This right shall include freedom to hold opinions and to receive and impart information and ideas without interference by public authority and regardless of frontiers. This Article shall not prevent states from requiring the licensing of broadcasting, television or cinema enterprises.

2. The exercise of these freedoms, since it carries with it duties and responsibilities, may be subject to such formalities, conditions, restrictions or penalties as are prescribed by law and are necessary in a democratic society, in the interests of national security, territorial integrity or public safety, for the prevention of disorder or crime, for the protection of health or morals, for the protection of the reputation or rights of others, for the disclosure of information received in confidence, or for maintaining the authority and impartiality of the judiciary."

In the Article 10 provision, the European Convention on Human Rights essentially protects freedom of speech. Included in the idea of speech is "symbolic" speech, which is not specified in the article, but which covers, inter alia, artistic works. Amongst the artistic works protected are visual art and creative writing, which are the media featured here. Unsurprisingly, it is freedom of expression rather than speech per se that is the Strasbourg system's preferred nomenclature for protection purposes in this area, and the term "expression" obviously has a special resonance in the artistic context now considered.
What sort of disputes concern us? The fundamental conflict between art and law under Article 10 occurs in the sphere of the proscription of immoral communications, an area that sometimes, lamentably, embraces morallycontroversial art. Art is not afforded a special place for public-moral purposes under the Convention; arguably, it should be. Art has a distinct ontology, and is culturally recognised as a discrete body of value, being emergent from the creativity of individuals, which has a certain spiritual significance, that is reflected, for example, in the French intellectual property term "oeuvres d'esprit" ("works of the mind/spirit"). From a purist, spiritual perspective, when art is pitched against public-moral considerations, the fruits of artistic expressivity should be accommodated and protected within the law's relevant tests and mechanisms. A personal opinion is that the philosophically- and culturally-recognised autonomy of art should invite special individual treatment of art by lawmakers so that any perceived "transgressions" of acceptable moral boundaries by it in a societal context are understood to be taking place within the artistic order, ie within art's normal internal canons of operation. This level of juridical selective treatment, as we will see, is yet to be achieved under the Convention, despite the alleged parity of each cultural sub-set of society, including art, within the central tenets of cultural recognition in the present era, which is sometimes philosophically known as egalitarian postmodernism.

\section{THE PERTINENT CASE LAW}

In Handyside v United Kingdom, E Ct HRR A 24 (1976), 1 EHRR 737, the applicant was the publisher of The Little Red 
Schoolbook, a book for children that included a chapter with subsections giving advice on sexual issues. He was prosecuted under the Obscene Publications Act 1959 and was convicted. By 13 votes to 1, the European Court of Human Rights held that the conviction was not a breach of freedom of speech under Article 10. In reaching this result, the court followed its own collective reasoning in terms which permitted a certain margin of appreciation or discretion to a defendant state in its assessment of what the public interest requires. In Handyside, which was later to be treated as a seminal case, the court pronounced that:

"[I]t is not possible to find in the domestic law of the various contracting states a uniform European conception of morals.

The view taken by their respective laws of the requirements of morals varies from time to time and from place to place, especially in our era which is characterised by a rapid and farreaching evolution of opinions on the subject. By reason of their direct and continuous contact with the vital forces of their countries, state authorities are in principle in a better position than the international judge to give an opinion on the exact content of these requirements...."

Unwittingly, the court thereby opened the floodgates for narrow, and even antiquated, "moral" standards in individual states to dictate the outcome of cases taken to it. This matters crucially because the court represents the summit of an appellate route the applicant expressly follows as the very consequence of his/her perceived unfairness of the narrowness of alleged domestic/national "moral" conceptions, in the hope that the Strasbourg court will take, as its remit suggests, a broader and more enlightened approach to "morality", unconnected with merely local, harmfully parochial scruples.

In the next relevant case, the Commission, in $X$ and $Y_{V}$ United Kingdom, 28 DR 77 (1982), held that the applicant's conviction for the controversial crime of blasphemy was not a breach of Article 10. In that case, a poem and accompanying illustration depicting the sexual activity of a contemporary male soldier with the body of the dead Christ was the source of the complaint. It was not suggested in Strasbourg that because the material had featured in Gay News, which was designed for an audience of homosexual and bisexual people, the imagery may not have proved as potentially "depraving" (a very oldfashioned concept that assumes a sort of innocent purity in an audience of adults). In fact, the allegedly offensive material may not have reached anyone at all for whom it may have been allegedly harmful, given the limited number, as well as the specialised sexual orientation, of the readership. The Commission also entertained no thought that it might be highly relevant that the condemned work was art, which is not meant to be taken literally, but, rather, as an invitation to a reaction not dissimilar to that habitually pertaining to humour (art, like humour, having an oblique rather than a literal intention of operating, which should be rightly and properly considered, with due respect to its distinctive ontology, by any given adult audience).

In a subsequent consistent case, Muller v Switzerland, E Ct HRR A 113 (1991), 13 EHRR 212, the first applicant was an established artist who was convicted under a Swiss obscenity law for publishing obscene articles in an exhibition of contemporary art. The three paintings involved were said by the court of first instance to give free vein to licentiousness and even perversion, a circumstance morally offensive to the vast majority of the population. At the European Court of Human Rights, by a majority of 6 votes to 1 , it was held that the artist's conviction was not in breach of Article 10, a result which was said to be consistent with the Handyside ruling. In its judgment, the court opined:

"[C]onceptions of sexual morality have changed in recent years. Nevertheless, having inspected the original paintings, the Court does not find unreasonable the view taken by the Swiss courts that those paintings, with their emphasis on sexuality in some of its crudest forms, were [likely] ... to offend the sense of sexual propriety of persons of ordinary sensitivity."

The court followed its own approach on the "margin of appreciation" points formulated in Handyside, so the result it achieved is unsurprising. However, the paintings concerned had not given rise to a public outcry and the press was unqualifiedly on the artist's side. It was also true that the applicant, Muller, had been able to exhibit similar works in other parts of Switzerland without legal or other interference. What in effect transpired in Muller, then, was that the court used an even more provincial standard of art appreciation and moral over-sensitivity than in Handyside. By neglecting to impose its own moral standards based on its members' arguably greater life experience and greater maturity of vision as well as superior status, the court was clearly in dereliction of its duty. It should have considered, and then asserted, a meta-standard of artistic and moral insight consonant with its supra-national foundational role.

In the next case, Choudhury v United Kingdom, 12 HRLJ 172 (1991), the Commission held that the fact that blasphemy protected the feelings of only Christians was not a breach of Article 9 on freedom of religion. Although the Commission had only to deal with the Article 9 issue, the case had important possible implications for art and Article 10. Regarding the substance of the case, if a Christian, as opposed to a Muslim, had sought injunctions against Salman Rushdie and his publishers claiming that they had promulgated in Rushdie's novel, The Satanic Verses, a blasphemous libel, then the Commission might have been obliged to adjudicate on whether it was conceptually feasible that a work of fiction, of an imaginative not factual dimension, could ever be capable of conveying literal blasphemous thoughts on the part of its art-intentioned and art-expressive author. 
A similar line of enquiry could have been posed in relation to the important case of Otto-Preminger Institute $V$ Austria, E Ct HRR A 295-A (1994), 19 EHRR 34, Eur Ct HR. Here, the applicant Institute, which operated an "art cinema" in Innsbruck, wished to show a controversial film called Das Liebeskinzil. Institute members received a bulletin that was also posted elsewhere in Innsbruck stating that in the film "trivial imagery and absurdities of the Christian creed are targeted in a caricatural (sic) mode and the relationship between religious beliefs and worldly mechanisms of oppression is investigated". Despite the film possessing this serious artistic remit, in relevant Austrian courts, culminating in a decision by the Innsbruck Court of Appeal, the seizure and forfeiture of the film was permitted on the basis that Mr Zingl, the Institute manager, had committed the criminal offence of "disparaging religious doctrines". When the case went before the European Court of Human Rights, its judgment followed the Austrian courts' enmity towards the film, which it said portrayed:

"the God of the Jewish religion, the Christian religion and the Islamic religion as an apparently senile old man...."

It continued:

"Other scenes show the Virgin Mary permitting an obscene story to be read to her .... The adult Jesus Christ is portrayed as a low grade mental defective and in one scene is shown lasciously (sic) attempting to fondle and kiss her breasts, which she is shown as permitting."

The film's merit as a work of art was adjudged by the court not to outweigh its essential offensiveness to the local general public. This judgment was reached even though Article 17a of the Austrian Basic Law specifically protects freedom of artistic expression, and Article 10 of the European Convention on Human Rights protects freedom of expression generally, including artistic expression. The result of the case was surprising because the film was explicitly characterised by its promoters as an "art film" which was to be shown in an "art cinema". No-one of a relevant religious persuasion who did not wish to see it was in any way obliged to go to see it. Moreover, the "art film" was located within an appropriate "art" environment so the intended artistic impact of it was contextually clear. The film can therefore be easily legally defended and morally vindicated : the film was far from an imposition on local people, and it was designed to be viewed with the appropriate psychic and aesthetic attitude appropriate to art so that ordinary factual offence simply could not result. It was also situated in a place specifically designated for art appreciation, and art appreciation only. In view of this profile, the film could not fairly be judged to be a public hazard or to be literally blasphemous; its clear remit was artistic stimulus not factual irreverence.

In a following consistent case, Wingrove $v$ United Kingdom, 24 EHHR 1 (1997), the European Court of Human Rights had to adjudicate on whether a video film by the applicant was blasphemous, as had been decided by local censoring bodies in the United Kingdom. The film, Visions of Ecstasy, controversially portrayed the erotic experiences of a putative St Teresa of Avila with a figure representing Christ. The court upheld the validity of national blasphemy measures and emphasised yet again the doctrine of the "margin of appreciation" to avoid replacing the judgment of the national authorities with its own, pursuing the conveniently dismissive and politically expedient logic that the national organs were in a better position to judge local sentiments regarding blasphemy and related matters. The court thereby again declined to do its highly important duty to render considered justice as a human rights appellate court, electing instead to defer to the legal wisdom of national authorities despite the fact that the whole point of appealing to the European Court of Human Rights is to have an issue actively resolved by that superior court.

\section{POSTSCRIPT AND CONCLUSIONS}

What has happened more recently to the " public morality law against art" dynamic that the above cases exemplify? Article 10 on freedom of expression is not a much-used provision anyway, but it may be the case, firstly, that, in view of the seminal decisions adumbrated above, artists as a particular class are now relatively reluctant to turn to the European Court of Human Rights because its record for supporting them is less than distinguished. Secondly, it might also be the case that national laws are now more attuned to artistic processes, including their occasional, revolutionary moral excesses, and there is consequently a failure to prosecute. Thirdly, it might be the case that art in general has become less opposed to conventional morality in its various depictions. It is submitted, though, that it is premature to think that art's cultural autonomy is now recognised by a European-wide legal exemption from criminal investigation since such an exceptional category of immunity to legal process in this realm has not been officially pronounced upon or, even, more informally registered by arts critics and the general public.

In some written national constitutions, such as the Austrian and German models, art is explicitly deemed to be free. The above case-law analysis shows that even that sort of ultimate assurance does not necessarily guarantee a presumption in favour of artistic freedom when art traverses accepted conventional moral boundaries, even when it reaches the utmost appellate stage of legal proceedings in an endeavour to protect itself. Indeed, under the European Convention on Human Rights, not all aspects of freedom of expression have been adjudged by legal commentators to be equally valued. It is now alleged that a three-tiered scheme of priority of freedoms of expression have been established by the court: the most prized is freedom of political expression; this is followed in terms of importance by freedom of artistic expression; and 
freedom of commercial speech is said to be the leastprotected, or to put it another way, the most vulnerable freedom in the court's practice. It is the author's conviction that the correct order of such a hierarchy may have to be reappraised in view of the facts revealed by the above critique of the court's habitual practice. That analysis shows, quite conclusively, the severe degree to which artists have been disadvantaged when appearing before an important international body which was explicitly foundationally designed to protect rights such as those connected with honourable artistic enterprise. (c)

\section{Paul Kearns}

The author is a Lecturer in Law at the School of Law, University of Manchester. He specialises in art law, and his book "The Legal Concept of Art" was the first monograph on the subject to be published in the United Kingdom. 